\title{
KONTRIBUSI KHUTBAH JUM'AT DALAM PEMBINAAN KERUKUNAN ANTAR UMAT BERAGAMA DI MASYARAKAT (Studi Kasus Di Desa Anamina Kecamatan Manggelewa Kabupaten Dompu)
}

\author{
Fitriani $^{1}$ \\ STAI Al-Amin Dompu
}

\begin{abstract}
Friday's sermon is one means to create religious harmony. Through the Friday sermon the community can be given an understanding of the importance of living in harmony between religious people. Based on the results of the exposure in this journal it can be concluded that the background of the emergence of harmony between religious communities are: (1) The educational factor, most of the population who have received the education became more aware of the importance of maintaining harmony of life among religious people. It proves that their understanding of religious differences is no longer superficial, so the differences are not a pretext to overthrow each other. But it is all used as a means to be able to establish cooperation. (2) Conditions of environment, circumstances and circumstances conducive environment, in the sense that there is rarely and even never a conflict in the name of religion. It drove them away from the influence of secularism and sara issues that could lead to division. (3). Geographical location, viewed from geographical location, village Anamina Kec. Manggelewa Kab. Dompu which is located a bit isolated in the suburbs makes their lives become more secure and comfortable because it is protected from the harsh influence of city life that more presenting the principle of living individualism.

Keyword: Jum'at Purpose, Guidance Of Religious People Guidance
\end{abstract}

\begin{abstract}
Abstrak: Khutbah Jumat merupakan salah satu sarana untuk menciptakan kerukunan umat beragama. Melalui khutbah jumat masyarakat dapat diberikan pemahaman akan pentingnya hidup rukun antara umat beragama. Berdasarkan hasil pemaparan dalam jurnal ini maka dapat disimpulkan bahwa yang melatar belakangi timbulnya kerukunan hidup antar umat beragama adalah: (1) Faktor pendidikan, sebagian besar penduduk yang telah mengenyam pendidikan menjadi lebih tahu akan pentingnya menjaga kerukunan hidup antar umat beragama. Hal itu membuktikan bahwa pemahaman mereka tentang perbedaan agama tidak lagi dangkal, sehingga perbedaan bukan menjadi dalih
\end{abstract}

\footnotetext{
${ }^{1}$ Dosen pada Program Studi Pendidikan Agama Islam (PAI)di STAI Al-Amin Dompu
} 
untuk saling menjatuhkan. Akan tetapi itu semua dijadikan sebagai suatu sarana untuk dapat menjalin kerjasama. (2) Kondisi lingkungan, keadaan dan situasi lingkungan yang kondusif, dalam arti di sana jarang sekali dan bahkan tidak pernah terjadi suatu konflik yang mengatas-namakan agama. Hal itu menjauhkan mereka dari pengaruh sekulerisme dan isu-isu sara yang dapat menimbulkan perpecahan. (3). Letak geografis, ditinjau dari letak geografis, desa Anamina Kec. Manggelewa Kab. Dompu yang terletak agak terpencil di pinggiran kota membuat kehidupan mereka menjadi lebih aman dan nyaman karena terhindar dari pengaruh kerasnya kehidupan kota yang lebih menyuguhkan prinsip hidup individualisme.

Kata kunci: Khutbah Jum'at, dan Kerukunan Umat Beragama.

\section{Pendahuluan}

Dalam hidup bermasyarakat, keanekaragaman tidak bisa kita hindari karena itu semua sudah menjadi sunnatullah. Mulai dari beraneka ragamnya warna kulit sampai pada bermacam-macamnya agama, semua itu selalu menyertai kehidupan kita di dunia. Sebagai umat manusia yang berbudaya dan berakal dituntut untuk lebih bijaksana dalam menyikapi keadaan tersebut. Karena dalam kegiatan kita sehari-hari keanekaragaman atau pluralitas itu menjadi sesuatu yang sangat wajar dan bahkan harus. Tanpa keanekaragaman itu mungkin hidup kita akan terasa membosankan dan statis.

Pluralitas yang dewasa ini marak dibahas adalah tentang pluralitas agama. Bahkan belakangan ini wacana tentang pluralitas agama dan masalah-masalah yang mengitarinya semakin muncul ke permukaan. Buku-buku, tulisan-tulisan, mediamedia, dan acara-acara seminar, serta dialog seputar agama makin sering kita saksikan dalam berbagai tingkat, baik tingkat lokal, nasional, maupun internasional. Kecenderungan meningkatnya perbincangan seputar pluralitas agama dan hubungan antar umat beragama ini seakan tiada putusnya dan tidak akan mengalami masa kadaluarsa.

Banyak hal yang melatar-belakangi mengapa wacana ini semakin marak, pertama: perlunya sosialisasi bahwa pada dasarnya semua agama datang untuk mengajarkan dan menyebarkan damai dan perdamaian dalam kehidupan manusia. Kedua: wacana agama yang pluralis, toleran, dan inclusive merupakan bagian tak terpisahkan dari ajaran agama itu sendiri. Sebab pluralitas apapun, termasuk pluralitas 
agama, dan semangat toleransi dan inklusivisme adalah kesenjangan Tuhan yang tidak bisa diubah, dihalangi, dan ditutupi. Ketiga: ada kesenjangan yang jauh antara cita-cita agama dan realitas empirik kehidupan umat beragama di tengah masyarakat. Keempat: semakin menguatnya kecenderungan eksklusivisme dan intoleransi di sebagian umat beragama yang pada gilirinnya memicu terjadinya konflik dan permusuhan yang berlabel agama. Kelima: perlunya dicari upaya-upaya penyelesaian masalah-masalah yang berkaitan dengan kerukunan dan perdamaian antar umat beragama(Ahmad, 2001: ix).

Umat Islam sekarang ini telah mengalami kebangkitan yang sudah sejak lama bisa disaksikan oleh berbagai kalangan, termasuk oleh umat agama lain. Keberadaan Islam di dunia ini yang sebagai pencerah kehidupan terus berusaha untuk memberikan yang terbaik bagi siapa saja yang hidup berdampingan dengannya, termasuk menjaga kerukunan antar umat beragama dalam kehidupan masyarakat.

Demikian pentingnya menjaga kerukunan tersebut, maka umat Islam tidak merasa enggan bila harus berhubungan langsung atau bekerja sama dengan pemeluk agama lain. Justru mereka menganggap bahwa cara itulah yang terbaik yang mungkin harus dilakukan selama itu tidak melanggar batas-batas yang telah ditentukan oleh masing-masing agama yang mereka anut, dan mereka berharap hal tersebut bisa mempererat tali persaudaraan antar umat beragama dalam kehidupan mereka di masyarakat.

\section{Khutbah jum'at dan Materi yang disampaikan}

\section{Pengertian Shalat Jum'at:}

Shalat Jum'at adalah shalat dua raka'at sesudah khutbah pada waktu dzuhur, di hari Jum'at.(Rasyid, 1976: 123).

Shalat Jum'at hukumnya adalah fardhu 'ain, artinya wajib atas tiap-tiap lakilaki yang dewasa yang beragama Islam, merdeka dan tetap dalam negeri. Tidak wajib shalai Jum'at itu atas orang perempuan, anak-anak, dan orang yang sedang dalam perjalanan. Hal ini sesuai dengan firman Allah:

Yang artinya: "Hai-hai orang-orang yang beriman, apabila kamu diseru untuk sembahyang (mendengar adzan) pada hari Jum'at, maka bendaklah kamu segera mengingat Allah (sembahyang Jum'at) dan tinggalkeanlah jual beli (Al-Jumu'ab ayat 9)" 
Yang dimaksud dengan jual beli di sini adalah segala pekerjaan selain dari urusan shalat.

\section{Syarat-syarat wajib Jum'at:}

a. Islam, tidak wajib Jum'at atas orang yang bukan Islam.

b. Baligh (dewasa), tidak wajib Jum'at atas anak-anak.

c. Berakal, tidak wajib Jum'at atas orang bodoh atau orang gila.

d. Laki-laki, tidak wajib Jum'at atas perempuan.

e. Sehat, tidak wajib Jum'at atas orang yang sedang sakit.

f. Tetap dalam negeri, tidak wajib Jum'at atas orang yang dalam perjalanan (Rasyid, 1976: 125).

\section{Syarat sah mendirikan Jum'at:}

a. Hendaklah diadakan dalam negeri yang tetap yang telah dijadikan wathan (tempat-tempat), baik di kota-kota maupun di kampung-kampung, maka tidak sah mendirikan Jum'at di ladang-ladang yang penduduknya hanya tinggal di sana untuk sementara waktu saja. Di masa Rasulullah saw, dan di masa sahabat yang empat tidak pernah terdiri Jum'at melainkan di negeri yang tetap.

b. Berjama'ah, karena tidak pernah di masa Rasulullah saw, shalat Jum'at dilakukan sendiri-sendiri. Sekurang-kurangnya bilangan jama'ah, menurut pendapat sebagian ulama 40 orang laki-laki dewasa dari penduduk negeri, ulama yang lain mengatakan: lebih dari 40. setengah ulama lagi berpendapat: cukup dengan dua orang saja, karena sudah berjama'ah. Tentang bilangan ini, sungguh banyak sekali pendapat-pendapat yang menyatakan tentang bilangan jama'ah pada waktu shalat Jum'at.

c. Hendaklah dikerjakan di waktu dzuhur.

Sabda Nabi:

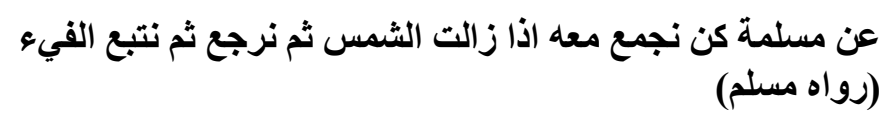

Artinya:Dari Maslamah: "Pernah kami sholat Jum'at bersama beliau (bersama Nabi) di saat setelah tergelincir matahari, kemudian kami pulang sambil mencari-cari bayangan tempat bertedub" (HR. Muslim) (Rasyid, 1976: 187).

d. Hendaklah shalat Jum'at didahului oleh dua khutbah. Sesuai dengan sabda Nabi:

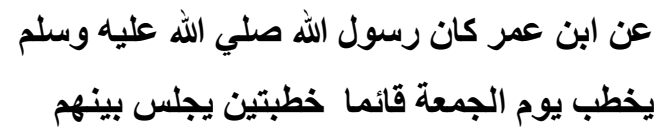




\section{(رواه البخاري ومسلم)}

Artinya: Dari Ibnu Umar: adalah Rasulullah saw, berkhutbah dua khutbah pada hari Jum'at dengan berdiri, dan beliau duduk di antara kedua khutbah itu" (Rasyid, 1976: 194).

\section{Rukun dua khutbah Jum'at:}

a. Mengucapkan puji-pujian kepada Allah. Keterangan amal Rasulullah saw, yang diterangkan oleh Muslim.

b. Shalawat atas Nabi Muhammad saw. Sebagian ulama berkata bahwa shalawat ini tidak wajib, berarti bukun merupakan rukun khutbah

c. Mengucap syahadat (bersaksi bahwa tidak ada Tuhan yang sebenarnya melainkan Allah dan bersaksi bahwa Nabi Muhammad adalah utusan-Nya)

d. Berwasiat (bernasehat) dengan taqwa dan mengajarkan apa-apa yang perlu kepada pendengar, sesuai dengan keadaan tempat dan waktu, baik urusan agama maupun urusan dunia seperti ibadah kesopanan, pergaulan, perekonomian, pertanian, siasat, dsb, serta dengan bahasa yang mudah dipahami oleh pendengar.

e. Membaca al-Qur'an pada salah satu khutbah. Sabda Nabi:

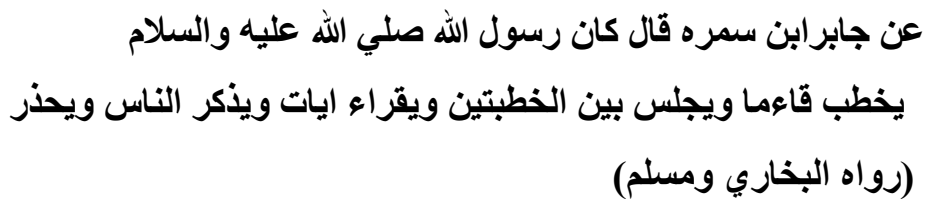

Artinya:Dari Jabir bin Samurah, katanya: "Adalah Rasullullah saw, berkhutbah dengan berdiri, beliau duduk di antara keduanya, lalu membaca beberapa ayat al-Qur'an, dan memperingatkan dan menakutinya." (HR. Bukhari dan Muslim) (Salam, 1993: 202).

\section{Keterangan:}

Menurut dzhahir hadits di atas, begitulah cara khutbah Nabi saw sebagaimana yang beliau ucapkan dalam khutbahnya itu, dan menunjukkan wajibnya melakukan cara semacam itu dalam berkhutbah, karena perbuatan Nabi itu sebagai penjelasan bagai apa yang telah dijelaskan secara global dalam surat Al-Jumuat: "Dan Nabi tekah bersabsa: (yang artinya): Sholatlah kamu semua sebagaimana kamu pernah meluhat aku shalat.

Mendo'a untuk mu'minin dan mu'minat pada khutbah yang kedua. Setengah ulama berpendapat bahwa do'a dalam khutbah tidak wajib sebagaimana juga di lain khutbah, tidak wajib (Al-Malibari, 1993: 460-464). 


\section{Syarat Dua Khutbah}

a) Hendaklah kedua khutbah itu dimulai sesudah tergelincir matahari, keterangan amal Rasulullah saw yang diriwayatkan oleh Bukhari.

b) Sewaktu berkhutbah, hendaklah berdiri jika kuasa, keterangan amal Rasulullah yang diriwayatkan oleh Muslim.

c) Khatib hendaknya duduk di antara dua khutbah, sekurang-kurangnya berhenti sebentar seukuran orang membaca al-fatihah, keterangan amal Rasulullah yang diriwayatkan oleh Muslim.

d) Hendaklah dengan suara yang keras kira-kira terdengar oleh para jama'ah Jum'at, karena yang dimaksud mengadakan khutbah itu, ialah untuk memberi pelajaran dan nasehat kepada mereka.

e) Hendaklah berturut-turut, baik rukunnya, atau jarak antara keduanya, maupun antar khutbah kedua dengan shalatnya.

f) Khatib hendaklah dalam keadaan suci baik dari hadats, baik kecil maupun hadats besar, dan juga dari najis, keterangan amal Rasulullah.

g) Khatib hendaklah menutup auratnya, keterangan amal Rasulullah (Rasyid, 1976: 128).

\section{Sunah Yang Berhubungan Dengan Khutbah}

a) Hendaklah khutbah itu dilakukan di atas mimbar, atau di tempat yang tinggi; keterangan amal Rasulullah saw, yang diriwayatkan oleh Bukhari dan Muslim. Mimbar itu terdiri atas tiga tangga dan tempatnya di sebelah kanan pengimaman shalat.

b) Khutbah itu diucapkan dengan kalimat yang fasih, terang, mudah difahami, sederhana, tidak terlalu panjang dan tidka pula terlalu pendek.

c) Khatib hendaklah tetap saja menghadap kepada jama'ah, jangan berputarputar, karena yang demikian itu tidak disyari'atkan.

d) Membaca surat al-Ikhlas sewaktu duduk antara dua khutbah.

e) menertibkan tiga rukun, yaitu dimulai dengan puji-pujian, kemudian shalawat atas Nabi, kemudian berwasiat. Selain dari pada itu tidak ada ketentuan harus tertib.

f) Si pendengar hendaklah diam serta memperhatikan khutbah. Banyak ulama mengatakan: Haram bercakap-cakap ketika mendengar khutbah. Akan tetapi 
menurut Imam Syafi'i dalam kitab yang lain di sebutkan hal itu tidak sampai pada hukum haram, akan tetapi hanya dihukumi makhruh saja. Makhruh juga bagi orang yang masuk masjid (di tengah-tengah khutbah) mengucapkan salam, sekalipun tidak mengambil tempat untuk dirinya, sebab hal ini akan merepotkan hadirin Jum'at yang diberi salam.

g) Khatib hendaklah memberi salam.

h) Khatib hendaklah duduk di atas mimbar sesudah memberi salam dan sesudah duduk itulah, adzan dilakukan (Rasyid, 1976: 130).

\section{Tujuan Khutbah Jum'at}

Tujuan khutbah diantaranya ialah:

a) Mengajak bertaqwa

b) Membangkitkan semangat amar- ma'ruf nahi-munkar (berusaha menegakkan dan melaksanakan syari'at agama Islam).

c) Memupuk atau membina persatuan dan persaudaraan di kalangan umat Islam khususnya, dan menggalang persatuan dan hidup rukun di antara sesama umat manusia. Bersama-sama membangun masyarakat yang sejahtera, adil makmur di bawah ampunan dan ridha dari Allah swt.

d) Mempererat jalinan kekeluargaan dan silaturrahiem (Suhaemi, 1985: 12).

\section{Persiapan Materi Khutbah}

Sebelum menyampaikan khutbah, khatib perlu untuk memilih materi yang akan disampaikan supaya nantinya bisa lebih mengena kepada para jama'ah Jum'at, persiapan itu antara lain yaitu:

a) Mencari judul khutbah yang sesuai dengan keadaan para jama'ah Jum'at.

b) Apabila mengambil materi khutbah yang telah ada dianjurkan membacanya lebih dahulu (jika perlu beberapa kali), sehingga ketika mengucapkan khutbah bisa benar-benar telah lancar. Bahkan dapat menambah atau mengurangi selama tidak menyimpang dari pengertian yang terkandung di dalamnya.

\section{Kerukunan Antar Umat Beragama}

\section{Akar Ideologis Kerukunan Antar Umat Beragama Menurut Faham Islam}

Islam memandang sebuah perbedaan sebagai sebuah berkah dan rahmat. Hal ini sesuai dengan sabda nabi "perbedaan di kalangan umatku adalah suatu berkab". 
Dengan demikian Islam tidaklah merisaukan adanya berbagai macam agama yang terdapat di lingkungan sekitarnya, mereka justru menganggapnya sebagai suatu fitrah dari Allah. Adanya langit dan bumi beserta isinya yang diciptakan berpasangpasangan sudah bisa dijadikan bukti kuat bahwa Allah sendiri memang menghendaki adanya perbedaan itu. Kita sebagai manusia hanyalah ditugaskan untuk menjalani hidup ini sesuai dengan tugas kita yaitu sebagai khalifah fi-al ardh.

Munculnya berbagai macam agama di sekitar kita merupakan salah satu dari fitrah tersebut. Kita umat Islam memang harus selalu waspada terhadap masalahmasalah keagamaan yang terjadi.

Agama-agama yang ada di dunia ini semata-mata bukanlah hasil pemikiran umat manusia; dan sebabnya adalah banyak. Agama-agama yang merata di dunia ini mempunyai ciri-ciri yang khas, yaitu sebagai berikut:

Pertama, menurut ukuran yang biasa, maka pembawa agama adalah orang-orang biasa. Mereka tidak mempunyai kekuatan dan kekuasaan yang tinggi (Departemen Agama RI, 1997: 41).

Sungguhpun demikian, mereka berani memberikan ajaran, baik kepada orang-orang besar maupun orang-orang kecil; dan dalam waktu yang tertentu mereka dengan pengikut-pengikutnya mengikat dari kedudukan yang rendah sampai kepada kedudukan yang tinggi. Ia membuktikan bahwa mereka ini dibantu oleh Kekuasaan Yang Maha Agung.

Kedua, semua pembawa agama itu adalah orang-orang yang sejak sebelum jadi Nabi dihargai dan dinilai tinggi oleh mesyarakatnya karena ketinggian budi pekertinya, sekalipun oleh orang-orang yang kemudian hari menjadi musuhnya, setelah mereka itu menyatakan tentang kenabiannya (Departemen Agama RI, 1997: 42).

Oleh karena itu, tidak masuk akal sama sekali, bahwa mereka yang tidak pernah dusta terhadap manusia, dengan serta merta berdusta terhadap Tuhannya. Pengakuan yang universal tentang kesucian dari kehidupannya, sebelum mereka itu menyiarkan agama yang mereka bawa, adalah suatu bukti tentang kebenaran pengakuan mereka.

Ketiga, bahwa pembawa agama itu tidak mempunyai kekuatan dan alat-alat yang pada umumnya dapat dikatakan menjamin suksesnya pimpinannya. Umumnya 
mereka sedikit sekali mengetahui tentang seni atau kebudayaan pada masanya (Departemen Agama RI, 1997: 44).

Sungguhpun demikian, apa yang mereka ajarkan adalah sesuatu yang lebih maju dari sesuatu yang ada pada masa itu; tidak sama dengan apa yang berlaku pada masanya. Hanya pembawa agama yang benar sajalah yang dapat berbuat demikian itu. Oleh karena itu adalah mustahil bahwa orang yang tidak mengeti sama sekali tentang peradaban, kemajuan yang terdapat paa waktunya, setelah berbuat dusta kepada Tuhannya, akan mempunyai kekuatan yang luar biasa, hingga ajarannya itu dapat mengalahkan ajaran-ajaran yang ada pada waktu itu. Kemenangan yang demikian itu adalah mustahil tanpa adanya bantuan dari Tuhan Yang Maha Kuasa.

Keempat, apabila diperhatikan, ajaran-ajaran yang dibawa oleh pembawa agama itu, maka dapat diketahui bahwa ajaran-ajaran nya selalu bertentangan dengan pikiran yang hidup pada waktu itu. Apabila ternyata ajaran-ajaran tersebut mempunyai kesamaan dengan pikiran yang sedang berkembang pada masanya, maka apa yang diajarkan itu adalah merupakan pernyataan ari pikiran-pikiran yang muncul pada waktu itu saja (Departemen Agama RI, 1997: 45).

Demikianlah dalam al-qur'an dijelaskan dengan tuntas bagaimana sebenarnya agama itu diturunkan dan dengan melalui perantara yang seperti apa, hal tersebut sudah demikian jelasnya. Oleh karena itu kita tidak diperbolehkan untuk menghina agama lain, dan menganggap agama kita yang paling benar di dunia ini.

\section{Faham-Faham Yang Lahir Dari Ideologis Kerukunan Antar Umat Beragama}

a. Pluralisme Agama

Pluralisme agama (religious pluralism) adalah sebuah paham (isme) tentang 'pluralitas'. Paham, bagaimana melihat keragaman dalam agama-agama. Mengapa dan bagaimana memandang agama-agama, yang begitu banyak dan beragam. Apakah hanya ada satu agama yang benar atau semua agama benar (Islamia, 2005: 27-28).

Pluralisme agama sebenarnya telah menjadi teori dalam filsafat agama. Menurut John Hick, salah satu tokoh utama paham religious pluralism, terminology "religious pluralism," menurutnya merujuk pada suatu teori hubungan antara agamaagama dengan segala perbedaan dan pertentangan kaliam-klaim mereka. Pluralissme, secara eksplisit menerima posisi yang radikal yang diaplikasikan oleh inklusivisme: yaitu suatu pandangan bahwa agama-agama besar mewujudkan persepsi, konsepsi, 
dan respon yang berbeda-beda tentang "The Real" atau "The Ultimate", juga bahwa tiap-tiap agama menjadi jalan untuk menmukan keselamatan dan pembebasan. Intinya, John Hick mengajukan gagasan pluralisme sebagai pengembangan dari inklusivisme. Bahwa, agama adalah jalan yang berbeda-beda menuju pada tujuan (The Ultimate) yang sama (Islamia, 2005: 28).

Dalam The Oxford English Dictionary disebutkan, bahwa pluralisme ini dipahami sebagai:

1) Suatu teori yang menentang kekuasaan negara monolitis; dan sebaliknya, mendukung desentralisasi dan otonmi untuk organisasi-organisasi yang mewakili keterlibatan individu dalam masyarakat, juga suatu keyakinan bahwa kekuasaan itu harus dibagi bersama-sama di antara sejumlah partai politik.

2) Keberadaan atau toleransi keragaman etnik atau kelompok-kelompok cultural dalam suatu masyarakat atau negara, serta keragaman kepercayaan atau sikap dalam suatu badan, kelembagaan, dan sebagainya.

Definisi yang pertama mengandung pengertian pluralisme politik, sedangkan yang kedua mengandung pengertian pluralisme sosial/primordial (Islamia, 2005: 21).

a. Liberalisme

Ada dua jenis Liberalisme Islam. Jenis yang pertama berpandangan bahwa ide Negara Islam liberal dimungkinkan dan diperlukan Karena Islam memiliki semangat yang demokratis dan liberal, dan terutama karena, di bidang politik, Islam tidak banyak memiliki ketentuan khusus. Jenis yang kedua memiliki pandangan yang sebaliknya.

Pandangan kelompok liberal pertama ialah bahwa Islam sedikit, atau tidak, memiliki ketentuan mengenai lembaga politik, dan tidak banyak tuntutan keagamaan yang diwajibkan pengamalannya kepada otoritas politik masa kini atau unsur-unsur di bawahnya. Kaum liberal Islam kategori pertama ini tidak menyatakan bahwa Islam memisahkan agama dari Negara (Binder, 2001: 355).

Mereka justru berpendapat bahwa kebisuan Islam terhadap pertanyaan seputar lembaga Negara mengisyaratkan bahwa kaum Muslim dibolehkan membentuk institusi liberal jika mereka menghendaki demikian. Bahkan, mereka cenderung menyimpulkan, dari kebisuan syari'ah terhadap perkara institusi politik, bahwa Islam hanya cocok dengan system liberal di mana kaum Muslimin bebas 
memilih dan mengubah struktur politik mereka. Meski begitu, Negara yang mereka usulkan tetaplah Negara Islam.

Jenis liberalisme Islam kedua, membenarkan dibentuknya insititusi-institusi liberal (parlemen, pemilu dan hak-hak sipil) dan beberapa kebijakan kesejahteraan sosial, bukan berdasarkan tiadanya undang-undang Islam yang kontradiktif, melainkan berdasarkan ketentuan Islam yang sangat khusus, yang umumnya mereka kutip dari sumber-sumber keagamaan dan dari sejarah kekhalifahan awal (Binder, 2001: 356).

Tentu saja, hasil akhir yang demikian dianggap sebagai suatu penyimpangan, karena lembaga-lembaga yang liberal tidak melandaskan diri pada prinsip-prinsip politik liberal, epistimologi, dan moral (pluralisme, individualisme, kapitalisme, agnostisisme, empirisme, pragmatisme, toleransi, dsb). Lembaga ini brpijak pada hokum Islam yang bersumber pada wahyu Ilahi, misalnya ketentuan Qur'an mengenai musyawarah, atau mengenai penolakan terhadap kekuasaan tertinggi manusia atas manusia, atau ketentuan syari'ah mengenai "pemilihan" khalifah, atau hadits mengenai kesetaraan umat.

Dari perspektif orang muslim dan atas ajaran-ajaran al-Qur'an, kebebasan beragama secara fundamental dan hakiki merupakan suatu tindakan menghargai kedaulatan Tuhan dan misteri rencana-Nya untuk manusia, yang telah diberi keistimewaan hebat untuk membangun, atas tanggungjawab mereka sendiri, takdir mereka di dunia dan akhirat. Akhirnya, menghormati kebebasan manusia adalah menghormati rencana Tuhan.

b. Sekularisme

Menurut istilah, kata secular berasal dari bahasa latin saeculum, yang memiliki arti dengan dua konotasi waktu dan lokasi; waktu menunjukkan kepada pengertian "sekarang" atau "kini" dan lokasi menunjuk kepada pengertian dunia atau duniawi. Jadi saeculum berarti zaman ini atau masa kini, dan zaman ini atau masa kini menunjuk kepada peristiwa-peristiwa di dunia ini, dan itu juga berarti peristiwa-peristiwa masa kini (Munawwir, 1986: 51).

Tekanan makna diletakkan pada suatu waktu atau periode tertentu di dunia yang dipandang sebagai suatu proses sejarah. Pengertian sekular menunjuk kepada kondisi dunia pada waktu, periode atau zaman tertentu ini. Dari sini telah dapat kita 
lihat benih makna yang mudah dengan sendirinya berkembang secara alami dan logis ke dalam konteks eksistensial dunia yang selalu berubah di mana terjadi paham relativitas nilai-nilai kemanusiaan.

Adapun sekularisasi didefinisikan sebagai pembebasan manusia "pertama-tama dari agama dan kemudian dari metafisika yang mengatur nalar dan bahasanya". Hal ini berarti "terlepasnya dunia dari pengertian-pengertian religius dan religius-semu", terhalaunya semua pandangan dunia yang tertutup, terpatahkannya semua mitos supranatural dan lambang-lambang suci..." defatalisasi sejarah, penemuan manusia akan kenyataan bahwa dia ditinggalkan dengan dunia di tangannya, sehingga dia tidak bisa lagi menyalahkan nasib atau kemalangan atas apa yang ia perbuat dengannya. Manusialah yang mengalihkan perhatiannya lepas dari dunia-dunia di atas sana ke arah dunia sini dan waktu kini (Munawwir, 1986: 51).

Sekularisme adalah sebuah gerakan yang menyeru kepada kehidupan duniawi tanpa campur tangan agama. Ini berarti bahwa dalam aspek politik, pemerintahan juga harus berdasar pada sekularisme (Najiyulloh, 2002: 281).

\section{Kontribusi Khutbah Jum'at dalam Pembinaan Kerukunan}

1. Di Lingkungan Keluarga

Peranan pendidikan dalam sebuah keluarga sangatlah dominan, hal ini dikarenakan masa depan anak akan lebih terjamin jika pendidikannya terpenuhi, baik itu pendidikan umum maupun pendidikan agama. Untuk pendidikan umum orang tua bisa menyekolahkan anaknya di sekolah-sekolah umum yang telah disediakan. Adapun orang tua ada juga yang memasukkan anaknya ke pondok pesantren untuk lebih memperkaya ilmu dan kepahamannya terhadap ilmu agama sebagai bekalnya di akhirat nanti.

Pendidikan dalam keluarga sangat memerlukan partisipasi dari semua pihak, baik itu dari kedua orang tua maupun dari anak itu sendiri. Dari orang tua partisipasi itu bisa berupa dorongan moral dan spiritual, serta fasilitas keagamaan di rumah, seperti Al-Qur'an dan buku-buku agama lainnya. Peran orang tua dalam membimbing serta mengarahkan anaknya ke jalan yang benar adalah sangat penting bahkan wajib. Karena itu semua merupakan tugas dan amanat sebagai orang tua. 
Dalam masyarakat yang heterogen terhadap masalah agama dan beberapa hal lain, sikap terbuka dan lebih toleran sangatlah dibutuhkan untuk membentuk suatu masyarakat yang aman, tenteram dan damai. Hal itu dapat dimulai dari kehidupan masyarakat kecil yaitu keluarga untuk menumbuhkan sikap rukun dan toleran terhadap perbedaan agama yang ada di sekitarnya. Adapun dampak positif dari khutbah Jum'at yang disampaikan di Desa Anamina Kecamatan Manggelewa Kabupaten Dompu antara lain adalah sebagai berikut:

a) Terbentuknya sebuah keluarga yang mampu menumbuhkan jiwa toleransi beragama terhadap anggota keluarga yang beragama lain, baik itu dalam pelaksanaan ibadah maupun terhadap keyakinan yang dimiliki oleh masingmasing anggota keluarga.

b) Dalam melaksanakan ibadah, antara anggota keluarga yang satu dengan yang lainnya bisa saling memahami, sehingga masing-masing bisa menjalankan ritual keagamaan tanpa ada rasa saling terganggu.

c) Dalam masalah pendidikan, dari pihak orang tua saling bertoleransi, dalam arti apakah anak nantinya akan disekolahkan ke sekolah Islam ataukah Kristen, mereka cenderung menyerahkan pilihan itu kepada anak, karena mereka (orang tua) tidak mau memaksakan kehendaknya kendati mereka berbeda agama.

d) Demikian juga mengenai masalah agama, tidak ada sedikitpun paksaan kepada anak untuk mengikuti suatu agama dari salah satu orang tuanya. Karena bagi orang tua yang telah memutuskan untuk menikah dengan orang yang berlainan agama, perbedaan agama hanya dianggap sebagai suatu perbedaan jalan menuju tujuan yang sama, yaitu Tuhan Yang Esa. Sehingga mereka lebih memilih memberikan kebebasan kepada anak untuk memilih agama sesuai dengan keyakinan mereka masing-masing.

e) Ketika dihadapkan pada masalah pernikahan, keluarga yang berlainan agama lebih menekankan kepada anaknya untuk memelih pasangan yang seagama. Hal ini dimaksudkan oleh orang tua, agar kehidupan rumah tangga anak tidak mengalami masalah yang sama seperti kedua orang tuanya. Karena dalam keluarga yang heterogen dalam masalah agama, 
meskipun satu sama lain bisa saling memberikan toleransi akan tetapi masih saja ada beberapa hal yang tidak bisa ditoleransi, seperti melakasanakan ibadah bersama-sama dengan anggota keluarga yang lain, misalnya pada waktu Puasa (bagi umat Islam), atau pada Misa Kebaktian (bagi umat Nasrani).

f) Pada saat mereka yang berlainan agama dihadapkan pada perayaan hari besar dari pasangannya, masing-masing dari mereka memilih untuk bertoleransi dan berbagi. Karena bagi mereka inti dari perayaan itu adalah sama saja, yaitu untuk mensyukuri akan sebuah peristiwa keagamaan warisan dari leluhur mereka. Jadi meskipun tidak ikut merayakan, mereka satu sama lain tetap saling membantu untuk mempersiapkan keperluannya, seperti yang terjadi di keluarga P. Misdi yang kebetulan istrinya adalah seorang Nasrani, ketika tiba Hari Raya Idul Fitri, sang istri juga ikut bersilaturrahmi ke rumah mertuanya untuk sungkem meminta maaf dan dia juga menyiapkan kue serta hidangan khas lebaran. Demikian juga jika hari Natal tiba, P. Misdi yang seorang Muslim, ikut pula menghias pohon Natal dan mengantarkan anak serta istrinya ke Gereja. Demikianlah sebagian dari dampak dari khutbah Jum'at yang disampaikan di Desa Anamina Kecamatan Manggelewa Kabupaten Dompu bagi kehidupan keluarga, baik yang agamanya sejenis maupun yang agamanya campuran.

2. Dalam Masyarakat

Kontribusi khutbah Jum'at di masyarakat bisa dirasakan dengan semakin meningkatnya semangat dan kerja sama yang mereka lakukan dengan orang non Islam di berbagai bidang, di antaranya adalah:

a) Mampu membentuk sesosok pribadi seorang Muslim yang toleran. Hal ini dibuktikan dengan meningkatnya kerjasama antara umat Kristen dengan umat Islam dalam hal membangun desa, misalnya: Diadakannya kerja bhakti setiap satu minggu sekali (dari kebiasaan sebelumnya yang dilaksanakan satu bulan sekali).

b) Munculnya kepahaman yang mendalam tentang pentingnya menjaga keutuhan dan kesucian ajaran masing-masing agama. Kepahaman itu dibuktikan dengan tidak adanya acara perayaan hari besar bersama antar umat 
beragama. Misalnya: Umat Islam diundang oleh umat Kristen (sebaliknya) dalam perayaan Natal. Jika hal itu dilakukan itu merupakan upaya pengaburan nilai keagamaan yang bisa merusak akidah agama.

Meskipun pada awalnya masih ada kalangan umat Islam yang turut serta merayakan Natal dan sekaligus berkunjung ke rumah orang Kristen. Akan tetapi itu hanya sebagian kecil saja dan setelah diselidiki ternyata orang yang melakukan itu adalah orang yang kebetulan berhutang budi kepada yang bersangkutan (orang Kristen). Jadi dia merasa sungkan jika tidak turut merayakan dan berkunjung ke rumahnya, akan tetapi sekarang sudah tidak pernah lagi terjadi setelah hal itu diketahui oleh tokoh agam setempat dan mereka dilarang untuk melakukannya.

a) Terciptanya rasa aman ketika melaksanakan ibadah, karena dalam jiwa mereka telah tertanam jiwa toleransi beragama dan juga mereka telah bisa menyikapi perbedaan agama tersebut dengan baik, sehingga antara umat Islam dan Nasrani tidak ada yang saling menghina terhadap ritual dan aktifitas keagamaan masing-masing.

b) Tumbuhnya rasa tenggang rasa di kalangan masyarakat, dan rasa solidaritas yang begitu tinggi. Hal itu dibuktikan dengan adanya bela sungkawa yang secara alamiah terjadi ketika salah satu tetangga mereka tertimpa musibah.

c) Dalam sebuah perkumpulan atau organisasi dalam masyarakat, para pengurus sengaja mengambil anggota dari berbagai kalangan dan berbagai agama, hal ini dimaksudkan agar masyarakat tidak terpicu oleh perbedaan agama dan strata sosial yang bisa menghambat proses pembangunan di masyarakat itu sendiri.

d) Terciptanya rasa kebersamaan dan interaksi yang baik dalam lingkungan masyarakat, misalnya ketika ada salah satu anggota masyarakat yang sedang mempunyai hajatan, mereka akan mengundang para tetangganya tanpa membedakan antara Muslim dan Nasrani.

e) Semakin meningkatnya kesadaran akan pentingnya menjaga kerukunan antar umat beragama di masyarakat, karena meskipun masyarakat desa Anamina Kec. Manggelewa Kab. Dompu mayoritas beragama Islam, akan 
tetapi mereka tidak 'mengasingkan' umat lain (umat Kristen) yang sebagai kelompok minoritas. Kerukunan dan toleransi tetap bisa terjaga.

Sebagai bukti ringan dari pernyataan tersebut adalah dalam pembagian tugas masing-masing ketika kerja bhakti. Sebagai tambahan informasi, bahwa kerja bhakti dilakukan pada hari minggu bertepatan dengan pelaksanaan ibadah umat Kristen. Lantas bagaimana mereka mengatasinya. Pertama mereka membagi tugas kerja bhkati menjadi dua kelompok. Kelompok yang pertama yang terdiri dari orang Muslim, bertugas memotong dan mencabuti rumput. Kemudian kelompok yang kedua yang terdiri dari orang Kristen bertugas untuk menyapu dan mengumpulkan potongan rumput yang telah mongering.

Pembagian tugas yang teramat sederhana itu memang terlihat sangat sepele. Akan tetapi makna yang terkandung di dalamnya sangatlah mendalam. Ini membuktikan bahwa sekecil apapun masalah itu jika menyangkut tentang kerukunan, mereka akan menyikapinya secara bijaksana, agar mereka terbiasa untuk menerapkannya ke dalam konteks yang lebih pelik lagi. Itu semua dilakukan sematamata untuk memelihara kerukunan dan menghindari kecemburuan sosial di tengah masyarakat yang heterogen.

Masih banyak lagi sebenarnya manfaat lain yang diperoleh dari khutbah jum'at yang disampaikan di Desa Anamina Kecamatan Manggelewa Kabupaten Dompu. Yang penulis sebutkan di atas adalah sebagian kecilnya saja. Akan tetapi hal itu sudah mewakili dari apa yang terjadi di masyarakat Desa Anamina Kecamatan Manggelewa Kabupaten Dompu itu sendiri.

3. Dalam Membangun Kerukunan di Masyarakat

Dalam membina kerukunan hidup bermasyarakat, masyarakat desa Anamina Kecamatan Manggelewa Kabupaten Dompu telah berupaya untuk menggalakkannya. Di antaranya adalah:

a) Diadakannya kegiatan karang taruna yang anggotanya terdiri dari berbagai macam pemeluk agama. Meskipun organisasi ini tidak melulu mengurusi kegiatan keagamaan namun hal ini bisa mendorong terciptanya kerukunan, karena mereka yang berasal dari pemeluk agama yang berbeda bisa bekerja satu sama lain bahu-membahu membangun desa. 
b) Didirikannya perkumpulan kegiatan ibu-ibu dengan nama Perkumpulan Kerja Kelompok (PKK). Hal ini juga sangat membantu masyarakat dalam membina kerukunan. Karena seperti halnya Karang Taruna, anggota PKK juga berasal dari berbagai pemeluk agama. Hal ini dimaksudkan agar tidak ada beda antara mereka dalam hal mewujudkan kerjasama dan perdamaian di desa itu.

c) Dengan digalakkannya seruan tentang persatuan dan kerukunan, masyarakat desa perlahan mulai memahami pentingnya menjalin hubungan bermasyarakat dengan pemeluk agama lain. Untuk membuktikan partisipasi mereka dalam hal mewujudkan kerukunan masyarakat, mereka mengadakan kerja bhakti setiap hari minggu untuk membersihkan desa. Pekerjaan itu memang kelihatanya sepele, tapi mempunyai makna yang dalam bagi mereka. Dengan diadakannya kerja bhakti tersebut masyarakat bisa mengikis perbedaan keyakinan yang bisa memecah-belah kehidupan mereka.

d) Mendirikan perkumpulan olah raga sepak bola yang diikuti olah bapakbapak dan para pemuda desa untuk mempererat hubungan kekeluargaan dalam kehidupan masyarakat.

Itulah gambaran kehidupan masyarakat desa Anamina Kecamatan Manggelewa Kabupaten Dompu dan kontribusi khutbah Jum'at pada kehidupan mereka. Oleh karena itu para khatib hendaknya selalu memantau peristiwa di masyarakat agar senantiasa bisa mengatasi masalah yang terjadi agar tidak berlarut-larut dan semakin mambesar dan agar khutbahnyapun lebih mengena dan sesuai dengan fenomena di masyarakat.

\section{Catatan Akhir}

Berdasarkan pemaparan di atas dapat disimpulkan bahwa yang melatar belakangi timbulnya kerukunan hidup antar umat beragama adalah: (1) Faktor pendidikan, sebagian besar penduduk yang telah mengenyam pendidikan menjadi lebih tahu akan pentingnya menjaga kerukunan hidup antar umat beragama. Hal itu membuktikan bahwa pemahaman mereka tentang perbedaan agama tidak lagi dangkal, sehingga perbedaan bukan menjadi dalih untuk saling menjatuhkan. Akan tetapi itu semua dijadikan sebagai suatu sarana untuk dapat menjalin kerjasama. (2) 
Kondisi lingkungan, keadaan dan situasi lingkungan yang kondusif, dalam arti di sana jarang sekali dan bahkan tidak pernah terjadi suatu konflik yang mengatas-namakan agama. Hal itu menjauhkan mereka dari pengaruh sekulerisme dan isu-isu sara yang dapat menimbulkan perpecahan. (3). Letak geografis, ditinjau dari letak geografis, desa Anamina Kecamatan Manggelewa Kabupaten Dompu yang terletak agak terpencil di pinggiran kota membuat kehidupan mereka menjadi lebih aman dan nyaman karena terhindar dari pengaruh kerasnya kehidupan kota yang lebih menyuguhkan prinsip hidup individualisme.

Dengan disampaikannya materi tentang kerukunan, masyarakat menjadi semakin mengerti bahwa perbedaan keyakinan bukanlah suatu persoalan yang perlu didebatkan. Melainkan hal tersebut merupakan sunnatullah yang harus diterima dan dihargai, karena umat Islam adalah umat yang toleran terhadap orang lain. Jadi meskipun di Desa Anamina Kecamatan Manggelewa Kabupaten Dompu umat Islam adalah kelompok mayoritas, akan tetapi mereka tetap menghargai kelompok minoritas, yang dalam hal ini adalah umat Kristen dan Katholik yang hidup di sekitar lingkungan mereka.

\section{Daftar Rujukan}

A.Najiyulloh, Gerakan Keagamaan dan Pemikiran (Akar Ideologis dan Penyebarannya), AlI'tishom Cahaya Umat, Cet: III, 2002

Anas Soediyono, Pengantar Statistik Pendidikan, Jakarta, Rajawali Pers, 1987

Asmuni Syukir, Dasar-dasar Strategi Dakwah Islam, Al-Ikhlas, Surabaya, 1983

Asy-syekh Zaiunuddin Bin abdul Aziz Al-malibari, Fathul Mu'in, Al-Hidayah, Surabaya, 1993

Charles Kurzman, Ed, Wacana Islam Liberal (Pemikiran Islam Kontemporer Tentang Isu-isu Global), PARAMADINA, Jakarta, 2001

Departemen Agama Republik Indonesia, Al-Qur'an dan Terjemahnya, Mahkota Surabaya, tanpa tahun.

Imam Munawwir, Posisi Islam di Tengah Pertarungan Ideologi dan Keyakinan, PT. Bina Ilmu, Cet: I, Surabaya, 1986

Islamia, Thn I No.3/September-November, 2004 
Thn I No. 4 / Januari-Maret, 2015

Leonard Binder, Islam Liberal (Kritik Terhadap Ideologi-ideologi Pembangunan), Pustaka Pelajar, Jakarta, 2001

Mardalis, Drs. Metode Penelitian (Suatu Pendekatan Proposal), Bumi Aksara, Jakarta, 1999

Masrab Suhaemi Ah, Khutbah Jum'at Pilihan Anda, Cv. Karya Utama, Surabaya, 1985 